\title{
ETHANOL TO IMPROVE THE FUEL CONVERSION EFFICIENCY OF S.I. ENGINES IN THE BRAZILIAN MARKET
}

\author{
Paulo César de Ferreira Gomes ${ }^{1}$, Carlos Fernando Mendes ${ }^{1}$, Erwin Karl Franieck ${ }^{1}$, Gustavo \\ Santos Lopes ${ }^{1}$, Alysson Fernandes Teixeira ${ }^{2}$, José Guilherme Coelho Baeta ${ }^{2}$ \\ ${ }^{1}$ Robert Bosch Ltda. \\ ${ }^{2}$ Centro de Tecnologia da Mobilidade - UFMG \\ E-mails: paulo.gomes@br.bosch.com, carlos.mendes2@br.bosch.com, \\ erwin.franieck@br.bosch.com, external.lopes.gustavo@br.bosch.com, \\ alyssonft92@gmail.com, baeta@demec.ufmg.br
}

\begin{abstract}
In the next 15 years, the Brazilian government faces the difficult task of honoring the environmental commitment assumed at COP21 to reduce in $43 \%$ the GHG emission contributing to the global warming effect. It also has the challenge of ensuring a sustainable fuel supply for the transport sector. In this scenario, the RenovaBio program gives the directives to promote the use of biofuels as an important source of energy.

Besides the above-mentioned strategic aspects, the automotive market demands for the development of future technologies to improve the efficiency of the S.I. engines. With that in mind, the experimental work here described consisted of investigating the influence of the volumetric compression ratio, associated to internal EGR and airflow structure optimization (swirl and tumble) on the fuel consumption of a single cylinder research engine equipped with PFI and DI injection systems and running on E22 or hydrated ethanol.

The conclusion of the present work will show that it is possible to improve the fuel conversion efficiency by increasing the volumetric compression ratios above the ones used in the passenger cars sold in Brazil, and that ethanol has many advantages over the fossil fuel due to its antiknocking properties and environment friendliness.
\end{abstract}

\section{INTRODUCTION}

For the first time in history, in 2015 at COP 21 - the $21^{\text {st }}$ UN Conference of Parties, in Paris, it was signed a universal agreement to define actions to control the effects of climate changes. This agreement aims to limit the mean temperature rise to less than $2^{\circ} \mathrm{C}$. In August 2016, the Brazilian Senate approved the voluntary commitment to reduce until 2030 in $43 \%$ the GHG that contribute to global warming. It was also defined a goal to increase the share of renewable fuels in the energy matrix.

In this context, the Brazilian Government launched in the end of 2016 the Program "RenovaBio", which aims to promote the growth of biofuels production in this country and to create favorable conditions for the development of a national program of "Sustainable Energy 
Efficiency" for the transport sector. The concept of Sustainable Efficient Energy includes the perspectives of Sustainability, Energy Efficiency and Energy Policy, which must contemplate articulated, synchronized and independent actions, under the threat of resulting in ineffective and counter-productive decisions if not treated that way [1].

Regarding the Energy Efficiency, it is urgent to define the investment policies that will guide the choice of the technological routes leading to a more competitive automotive industry in the global scenario. Another factor contributing to the reduction of the Green House Gases (GHG) emission is the development of engine technologies to foment the use of biofuels. In this aspect, Flex-Fuel vehicles produced in Brazil since 2003 must be improved for a more efficient use of ethanol.

Many ethanol properties contribute for a more efficient use of energy in the internal combustion engines. Its high octane number, high flame speed and high latent heat of vaporization are some of the properties that may be enablers for the development and use of new technologies to improve the engine performance and efficiency. The development of high-compression ratio engines may take advantage of its anti-knocking properties and reduce their fuel consumption.

It is also important to remember that the geometric compression ratio of Flex-Fuel engines manufactured nowadays in Brazil is optimal for gasoline use and limited by knocking combustion. Thus, the compression ratio (CR) of these engines is not ideal for ethanol use, since it has better anti-knocking properties than gasoline and could tolerate higher CRs and achieve higher efficiencies without knocking limitations. Therefore, the development of technologies that allow the use of CR according to the selected fuel will surely result in the improvement of the engine energy efficiency and contribute to the environmental sustainability.

Today the development of innovative solutions to promote mobility in a sustainable way is one of the greatest challenges for the automotive sector. The relentless search for the reduction of fuel consumption and $\mathrm{CO}_{2}$ emissions comprises the development of new types of fuels [2], alternative sources of energy [3], and new technologies for the engines [4, 5, 6].

Downsizing, turbocharging, Atkinson and Miller cycles, cooled-EGR, variable compression ratios are in the technology road map as promising solutions to reduce the $\mathrm{CO}_{2}$ emissions. The present work focused in the application of high-CR to improve the ethanol fuel consumption of Flex-Fuel engines. It was necessary to combine high compression ratio with additional technologies in order to take full advantage of all the benefits offered by this biofuel.

The increase of the compression ratio is one of the most efficient design changes to reduce fuel consumption. High compression ratio has been used successfully in various vehicle applications [7, 8]. Ethanol has anti-knocking properties that make its use very attractive for high-CR engines. Having that in mind, the work here described consisted of investigating the influence of different geometric CR, associated to the introduction of internal exhaust gas recirculation (iEGR) and to the optimization of the primary flow structure, on the specific fuel consumption of a single cylinder engine equipped with PFI and DI injection systems using E22 and hydrated ethanol.

The use of high CR led to significant improvements of the fuel conversion efficiency. It also became evident the opportunity for the development of new technologies that will contribute for the reduction of fuel consumption and environmental pollution. This opportunity is unique 
for the Brazilian automotive industry to become competitive in the international scenario and to reduce its dependence on fossil fuels.

\section{EXPERIMENTAL SETUP}

\subsection{Single cylinder research engine (SCRE)}

In this experimental work, a single cylinder research engine that allows an easy change of the volumetric compression ratio and of the fuel injection system was used. This engine has two versions: one for performance evaluation and another for visualization of the combustion phenomena. The main characteristics of this engine are listed in the following table [9].

Table 1 - Main characteristics of the SCRE

\begin{tabular}{|l|l|}
\hline Number of cylinders & 1 \\
\hline Cylinder bore & $82 \mathrm{~mm}$ \\
\hline Stroke & $86 \mathrm{~mm}$ \\
\hline Swept volume & $450 \mathrm{~cm}^{3}$ \\
\hline \multirow{2}{*}{ Fuel injection system } & Direct injection side position, or... \\
\cline { 2 - 2 } & Port Fuel Injection \\
\hline Engine management system & AVL Engine Timing Unit 427 \\
\hline Idle speed & $800 \mathrm{rpm}$ \\
\hline Rated speed & $6000 \mathrm{rpm}$ \\
\hline Maximum speed, instantaneous & $6400 \mathrm{rpm}$ \\
\hline Cylinder peak firing pressure & $100 \mathrm{bar}$ \\
\hline Valves per cylinder & $4(2$ intake, 2 exhaust $)$ \\
\hline Fuel pump limit & 200 bar \\
\hline
\end{tabular}

Figure 1 illustrates the engine mounted on the engine test bench of the Mobility Technology Center - UFMG.

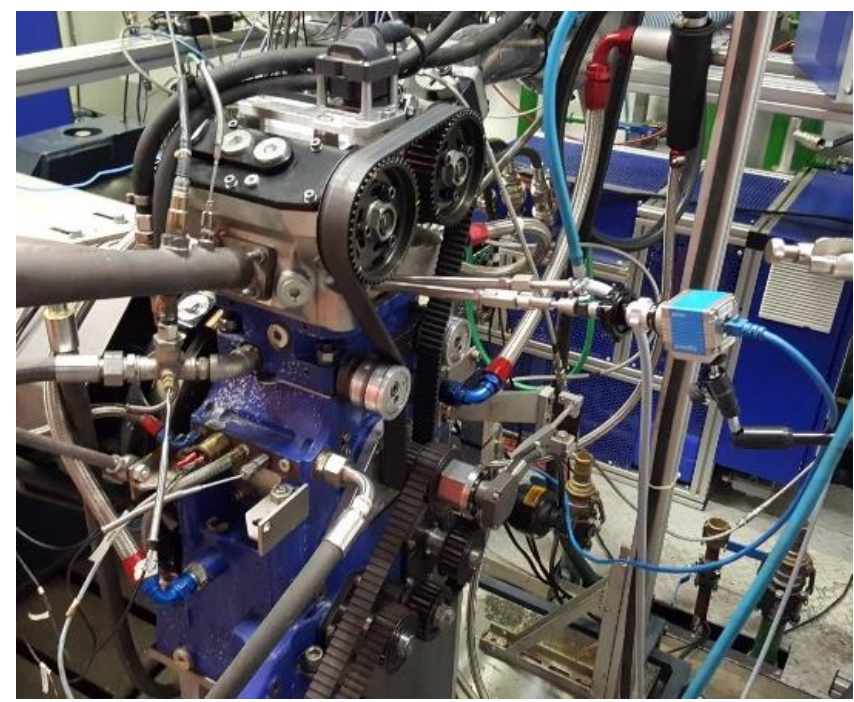

Figure 1. SCRE - Single Cylinder Research Engine mounted on the test bench of the Mobility Technology Center at the Federal University of Minas Gerais, Brazil. 


\subsection{Design of Experiment}

The test matrix consisted of 9 operating points that were chosen after the analysis of various FTP75 tests of vehicles equipped with engines that are expected to be the most produced in Brazil in 2022. The chosen points are the ones with the highest occurrence frequency during the FTP75 cycles and together represent approximately $63 \%$ of the cycle execution time. The percentage contribution of each point in the FTP75 cycle is shown in Table 2.

Table2. Weighting factors per point in the FTP75 cycle.

\begin{tabular}{|c|c|c|c|c|c|c|c|c|c|c|}
\hline & \multicolumn{10}{|c|}{ Weighting factor in the FTP75 cycle [\%] } \\
\hline \multirow{2}{*}{$\begin{array}{r}\text { BMEP } \\
\text { [bar] }\end{array}$} & \multicolumn{10}{|c|}{ RPM } \\
\hline & 500 & 1000 & 1500 & 2000 & 2500 & 3000 & 3500 & 4000 & 4500 & 5000 \\
\hline \multicolumn{11}{|l|}{1} \\
\hline 2 & & 20,300 & 2,900 & & & & & & & \\
\hline 3 & & 19,300 & & 5,081 & 6,200 & & & & & \\
\hline 4 & & & & 5,000 & & & & & & \\
\hline 5 & & & & & 3,600 & & & & & \\
\hline \multicolumn{11}{|l|}{6} \\
\hline \multicolumn{11}{|l|}{7} \\
\hline 8 & & & & 0,100 & 0,100 & & & & & \\
\hline WOT & & & & & & 0,400 & & & 0,003 & \\
\hline & \multicolumn{10}{|c|}{$63 \%$} \\
\hline
\end{tabular}

Besides these 9 points at partial load, two additional points at wide-open throttle, representing the conditions of maximum torque and power of the SCRE, completed the list of tested operating points. Figure 2 shows the 11 operating points chosen for the experiments on the SCRE.

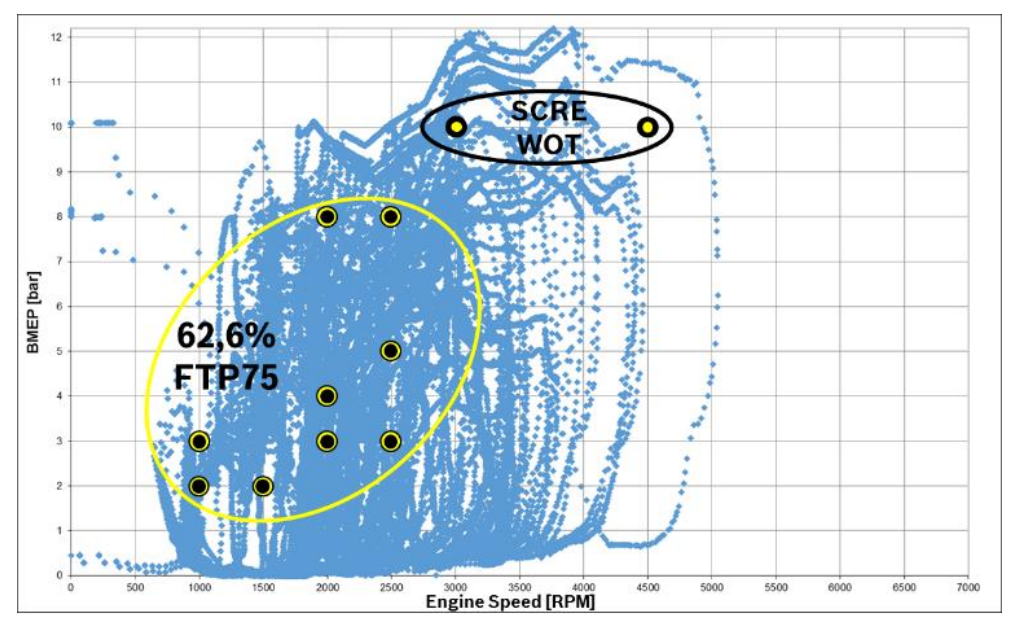

Figure 2. Records of load and engine speed variation during a FTP75 vehicle test and the 11 chosen points for the steady-state measurements on the SCRE

The CR was changed easily by shims mounted on the cylinder block of the single-cylinder engine as indicated in Figure 3. The CR of 11.5:1 was the baseline since it is the mean value of the compression ratios used by the Flex-Fuel vehicles produced nowadays in Brazil. The maximum CR used in the experimental tests was 15:1 because of geometric restrictions to avoid interference of the piston with the valves and the cylinder head. However, numerical simulations using ethanol and a CR of 16:1 revealed extra gains of efficiency. 


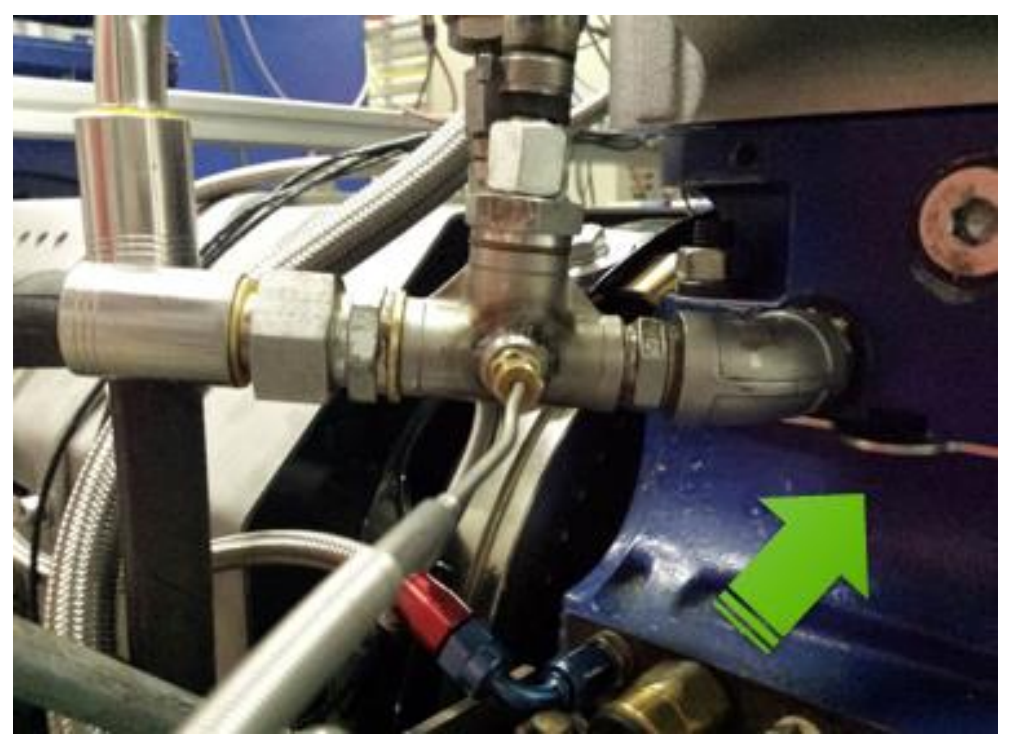

Figure 3. Spacer shims used for changing the SCRE compression ratio

For each compression ratio (11.5:1, 13:1 and 15:1), the engine was tested with E22 and E100 using two injection systems: DI with side mounted injector and maximum injection pressure of 80 bar; and PFI, with injection pressure of 3.5 bar.

The most efficient strategy to investigate the influence of iEGR on the engine knocking behavior, especially with gasoline at high compression ratio was the variation of the inlet valve opening time and the exhaust valve closing time. Despite of being efficient for the reduction of the temperature in the combustion chamber, and the mitigation of knocking events, this strategy has the side effect of reducing the speed of combustion and worsening the fuel conversion efficiency.

It was then necessary to optimize the primary flow structure to recover the turbulence levels prevailing in the combustion chamber before the introduction of iEGR and to maximize the gains originated from the use of $\mathrm{iEGR}$.

\section{RESULTS}

\subsection{Influence of the compression ratio variation on a PFI engine without iEGR}

Figure 4 shows the influence of the CR variation on the conversion efficiency of gasoline (E22) and hydrated ethanol (E100) on a PFI engine without iEGR. The values are the average of the 11 points of the test matrix and weighted according to the frequency of occurrence of each point in the FTP75 cycle as listed in table 2. 


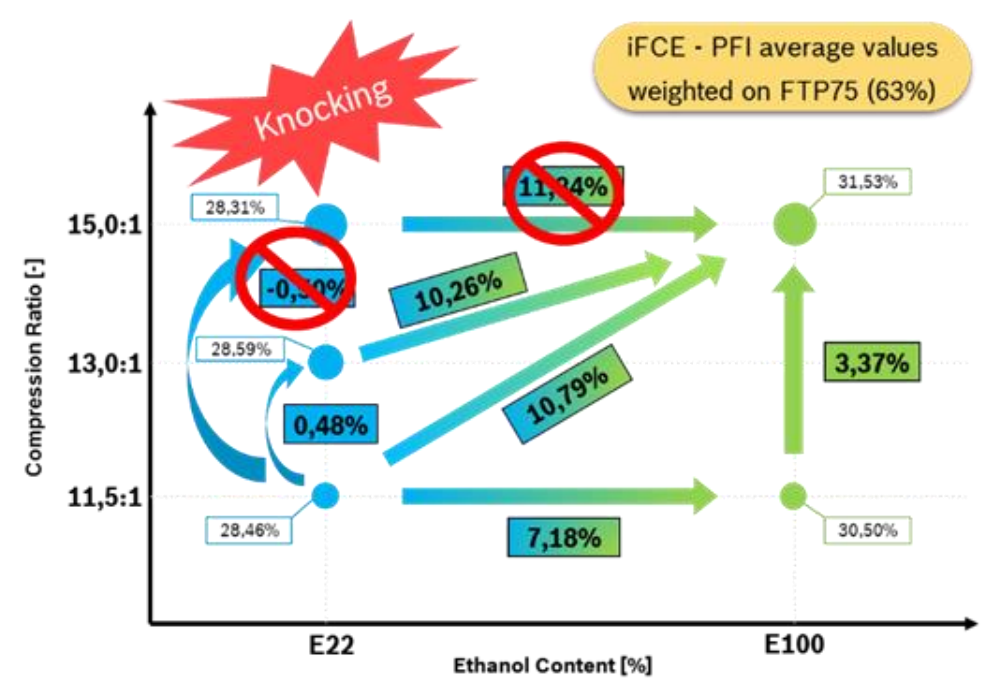

Figure 4. Influence of CR and fuel type on the Indicated Fuel Conversion Efficiency of the SCRE equipped with PFI injection system without iEGR.

The fuel conversion efficiency expresses the fraction of the total energy available in the fuel that is transformed into useful work and is calculated using the following equation:

$i F C E=\frac{360 \cdot P o t_{\text {ind }}}{L H V \cdot \dot{m}_{\text {fuel }}} \quad[\%]$

Where,

Pot ${ }_{\text {ind, }}$, indicated Power $[\mathrm{kW}]$;

$L H V$, Lower Heat value [MJ/kg];

$\dot{m}_{\text {fuel }}$, mass flow rate of fuel $[\mathrm{kg} / \mathrm{h}]$.

It may be observed that the increase of the CR from 11.5 to $13: 1$ resulted in a modest gain of the indicated conversion efficiency of gasoline, since at some operating points with CR 13:1 it was already necessary to retard the ignition timing in order to mitigate knocking. Using gasoline with CR of 15:1, heavy knocking occurred in almost every operating point, which eliminated the possibility of efficiency gains.

In case of ethanol that is a fuel with high octane number, increasing the CR to $15: 1$ led to an average efficiency gain of approximately 3.4\%. This efficiency improvement was greater for ethanol than for gasoline, in most operating points and resulted in fuel consumption reduction. One may infer from the measurements that the compression ratio of Flex-Fuel engines produced nowadays in Brazil can be optimized for ethanol use.

Figure 5 shows the weighted average specific fuel consumption as function of the compression ratio and the type of fuel used in a PFI version of the engine running without iEGR. It also shows the mean fuel consumption ratio between gasoline and ethanol. For this engine with a CR of 11.5, the fuel consumption ratio between gasoline and ethanol is approximately $74 \%$. 


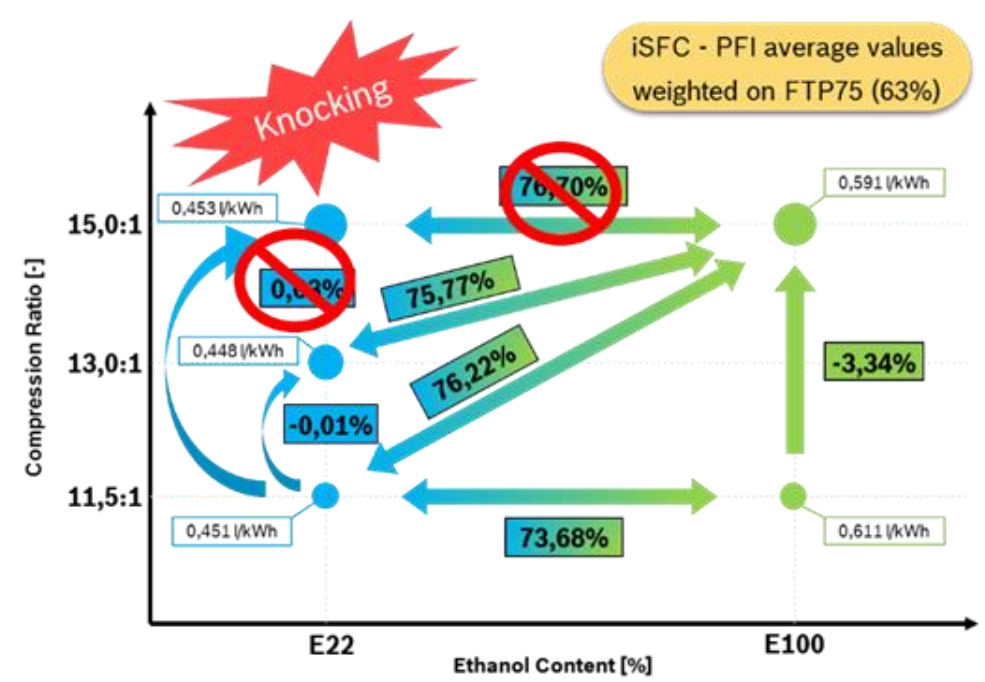

Figure 5 - Influence of CR and fuel type on the Indicated Specific Fuel Consumption [1/kWh] of a SCRE equipped with a PFI injection system without iEGR.

The ratio of the official low heat values of each liter of ethanol and gasoline is $69.3 \%$, approximately $70 \%$ for convenience, as illustrated in equation 2 and table 3 . That gave rise to the "70\% Paradigm", which is a rule of thumb that relies on the price parity between gasoline and ethanol to help the driver to choose the type of fuel, ethanol or gasoline, at the service station.

$\frac{L H V_{L_{-} e t h}}{L H V_{L_{-} g a s}}=0,693 \cong 0,70$

Table 3. Official Low Heat Value of Brazilian fuels [10].

\begin{tabular}{|c|c|c|c|c|}
\hline \multirow{2}{*}{ Fuel } & \multirow{2}{*}{$\begin{array}{c}\text { Density } \\
\mathrm{kg} / \mathrm{l}\end{array}$} & \multicolumn{2}{|c|}{ LHV } & \multirow{2}{*}{$\begin{array}{l}\text { LHV } \\
\text { Ratio }\end{array}$} \\
\hline & & MJ/kg & MJ/I & \\
\hline E22 & 0,745 & 38,92 & 29,00 & \multirow{2}{*}{0,693} \\
\hline E100 & 0,810 & 24,80 & 20,09 & \\
\hline
\end{tabular}

Even though this rule is widely used in Brazil, it does not apply correctly to internal combustion engines, since it assumes that the engine has the same fuel conversion efficiency for both types of fuel. Figure 5 also shows that an increase of the CR to 15:1 led to an ethanol consumption reduction of approximately $3.3 \%$ and that the average fuel consumption ratio of gasoline with the baseline configuration (CR 11.5:1) and the fuel consumption of ethanol at high CR $(15: 1)$ is $76.2 \%$. In similar situation, it would be advantageous from an economical point of view to refuel with ethanol if the price parity were over $70 \%$ and under $76 \%$.

\subsection{Influence of the compression ratio on a DI engine without iEGR}

The influence of the compression ratio variation on the fuel efficiency of a SCRE equipped with a DI system and a clean combustion chamber (without iEGR) was investigated with E22 and E100. Figure 6 shows the specific fuel consumption of E22. It revealed a clear tendency for lower specific fuel consumption as the load increased and as the CR increased from 11.5 to $15: 1$. The pumping losses decreased for higher loads and that is the reason for the observed efficiency improvement. 


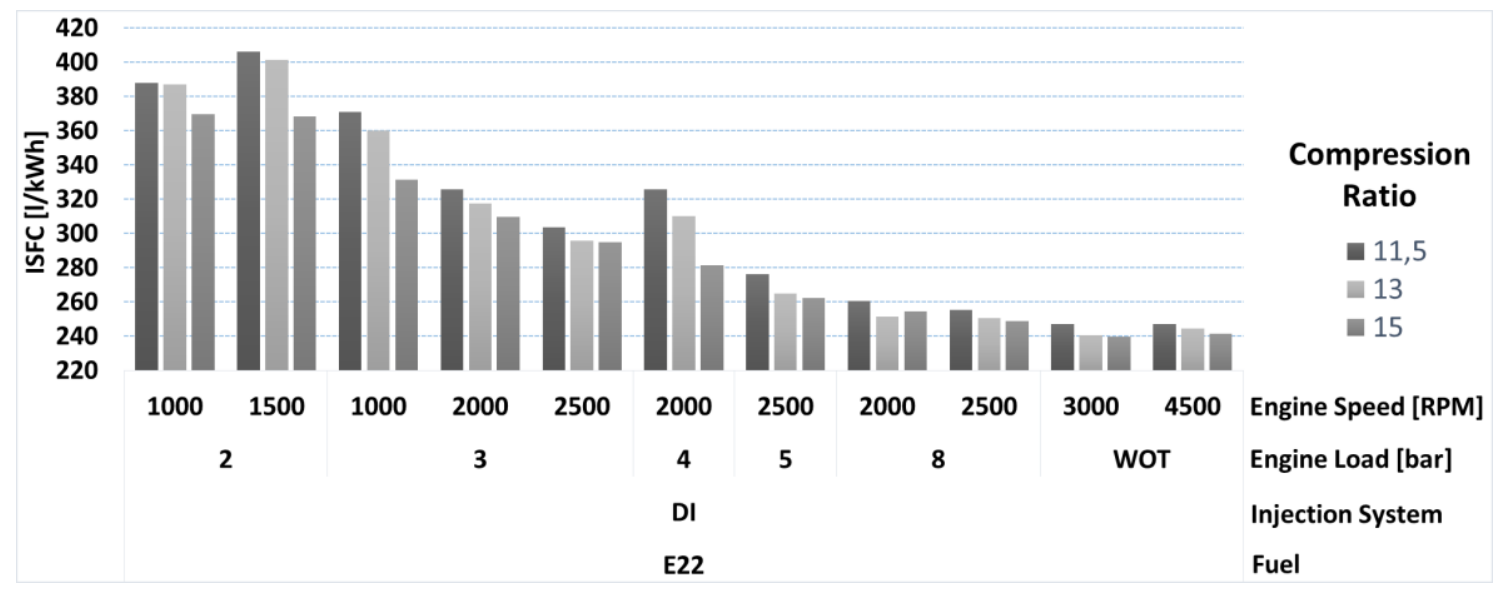

Figure 6 - Indicated specific fuel consumption of E22 for the 11 operating points with 3 different CRs

Figure 7 shows the specific ethanol consumption. The behavior is similar to the one observed with E22. As the load, the speed and the volumetric compression ratio increased, the fuel conversion efficiency improved and as consequence, the fuel consumption decreased.

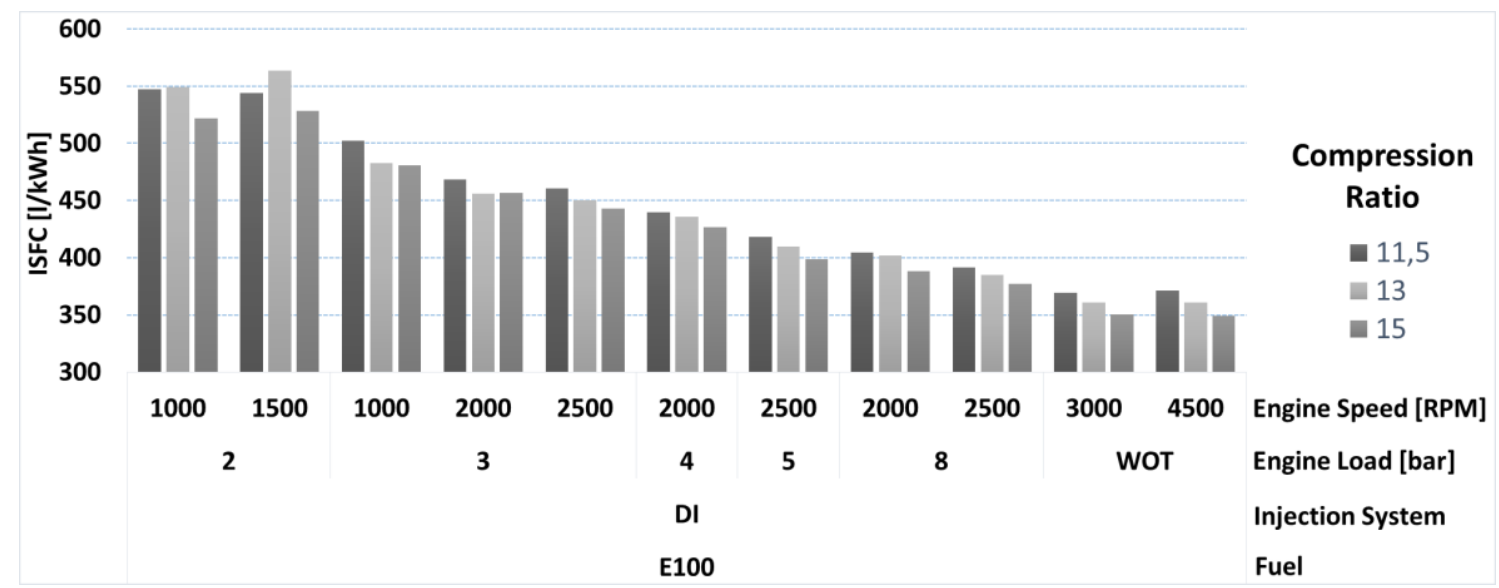

Figure 7 - Indicated specific consumption of E100 for the 11 operating points with 3 different volumetric compression ratios

It is important to mention the increase of the $\mathrm{NO}_{\mathrm{x}}$ emissions for higher CRs, due to higher temperatures and pressures in the combustion chamber. The use of E22 was restricted at high loads and high compression ratios, due to knocking events, as reported previously by Gomes et al. [11]. In such working conditions, it is better to use ethanol because of its physicochemical properties and high octane number as compared to E22. It is also worthy to say that the direct injection of fuel in the combustion chamber has a charge cooling effect that reduces the knocking tendency of DI engines.

\subsection{Influence of the internal exhaust gas recirculation on a PFI engine}

In order to investigate the influence of iEGR and different CRs on the fuel conversion efficiency and on the specific fuel consumption, the SCRE, with a PFI system, was tested at $2500 \mathrm{rpm}$ and loads of 3 and 5 bar iMEP, using gasoline and ethanol. A comparison of the engine behavior with clean combustion chamber (without iEGR) and dirty chamber 
(with iEGR) allowed a better understanding of the influence of different design parameters on the energy conversion efficiency and on the emission of pollutants.

One of the advantages of using iEGR is the reduction of the pumping losses. The most effective strategy to verify the influence of iEGR on the pumping losses was the early opening of the inlet valves. In figure 8 , it is possible to observe that the early opening of the intake valves led to a reduction of the Pumping Mean Effective Pressure (PMEP). This parameter relates to the pumping work and decreases as consequence of the wider opening of the throttle valve, which was necessary to compensate the additional residual gases in the combustion chamber. The reduction of fuel consumption was greater at low loads, since in these operating conditions the contribution of the pumping losses are more relevant.

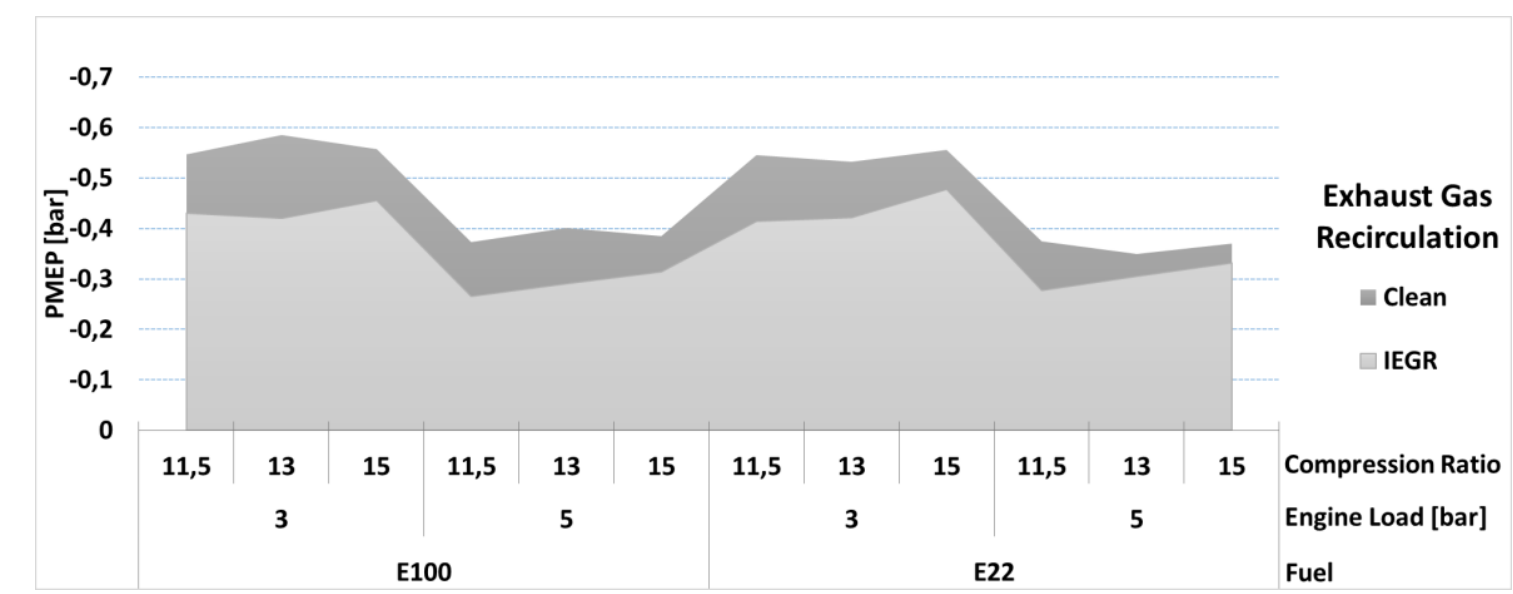

Figure 8 - Comparison of the pumping losses for clean and dirty combustion chamber.

Another benefit of iEGR was the reduction of the $\mathrm{NO}_{\mathrm{x}}$ emission, which resulted from better charge homogenization and lower peak temperature in the combustion chamber. This contributed also for the the mitigation of knocking when running on gasoline and high compression ratios. In addition, there was a reduction of the volumetric $\mathrm{CO}$ emission, which indicates a more efficient combustion resulting from the use of iEGR.

Despite of the various benefits originated from the introduction of internal exhaust gas recirculation, this technology promoted as side effect a slower combustion process. The results of figure 9 confirm this statement by indicating a longer duration of the fast combustion phase (MBF10-90).

In order to keep the MBF50 at 8 degrees crank after top dead center, figure 10 shows the need to anticipate the ignition timing with iEGR, as compared to the clean combustion chamber condition. 


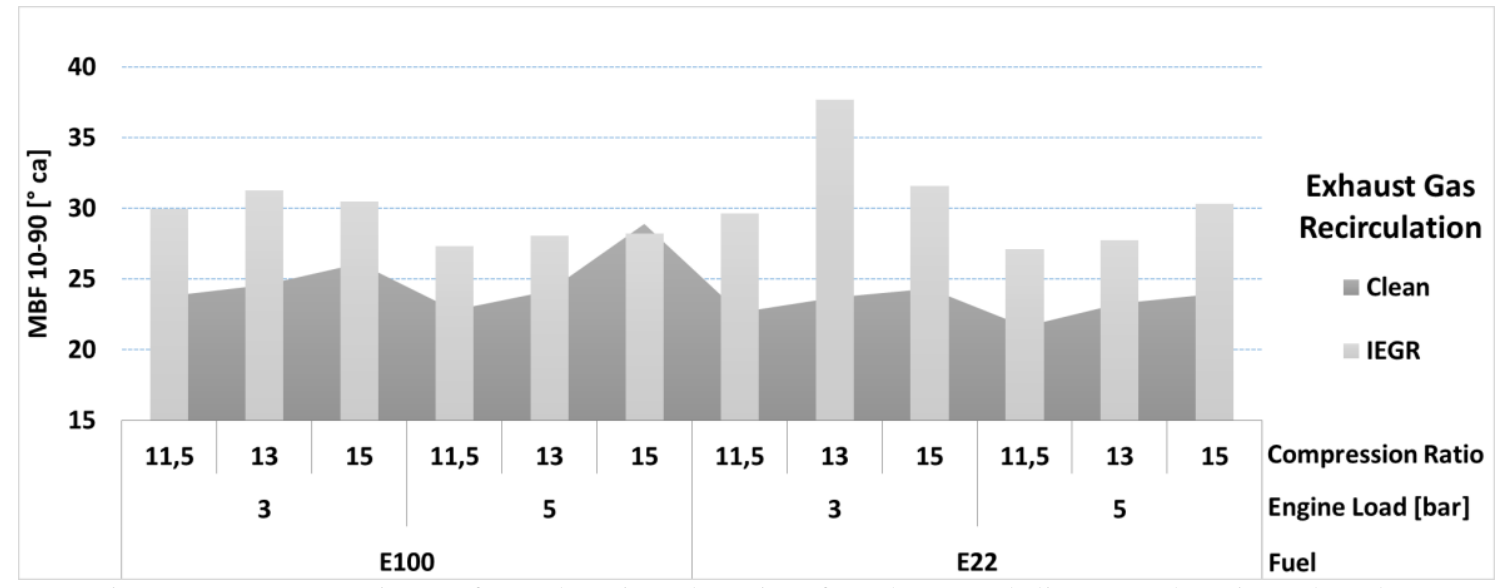

Figure 9 - Comparison of combustion duration for clean and dirty combustion chamber

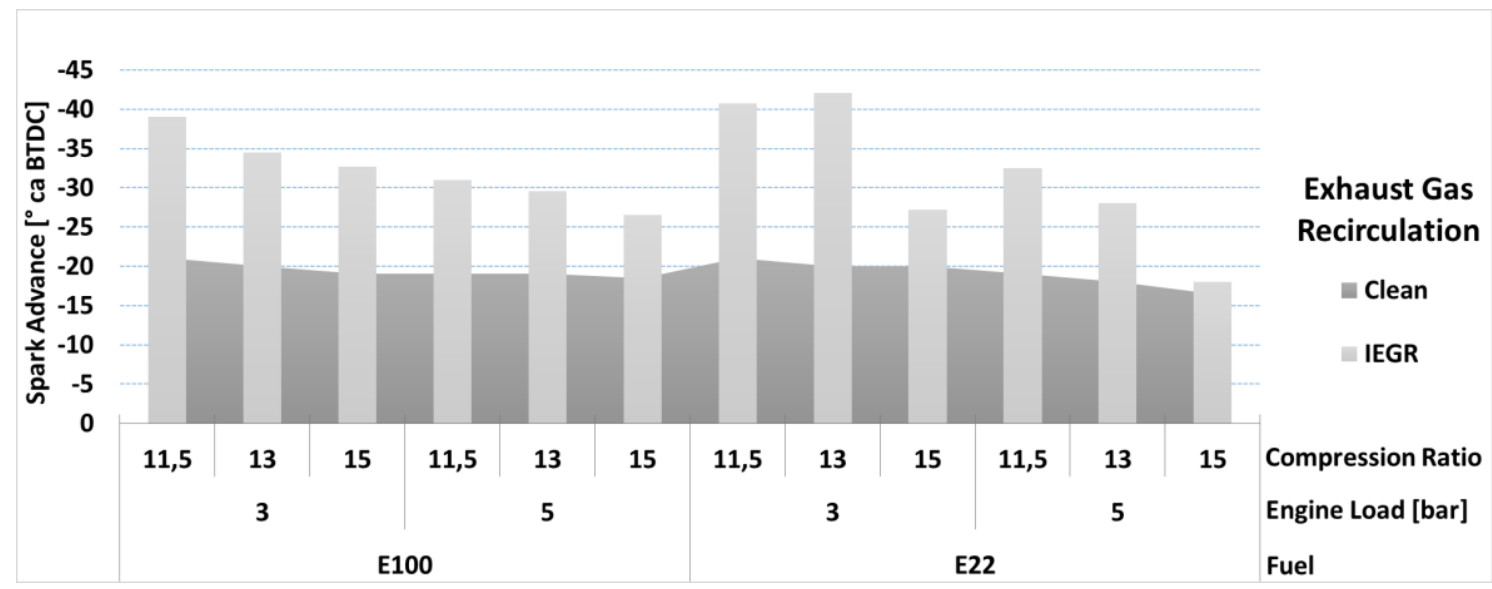

Figure 10 - Comparison of spark advance for clean and dirty combustion chamber.

Then it was evident the need for the optimization of the primary flow structure in order to regenerate the flame propagation speed and the flame stability in order to obtain the best benefits from the introduction of iEGR.

\subsection{Influence of the optimization of the primary flow structure (swirl and tumble).}

In this stage, the influence of the primary flow structure, associated to iEGR, on the combustion process was investigated.

In order to understand the gains of efficiency obtained from the association of CR, iEGR and primary flow structure, it is important to analyze their influence on the thermal and combustion efficiencies.

As indicated in equation (1), the fuel conversion efficiency expresses the ratio between the power generated by the engine and the energy value in the injected fuel.

The efficiency of combustion represents the ratio between the energy released by the burnt fuel and the energy value in the injected fuel. Equation (3) shows how to calculate the combustion efficiency by dividing the change of enthalpy between the reactants and products of combustion by the fuel mass flow rate multiplied by its lower heat value. 
$\eta_{\text {comb }}=\frac{H_{R}-H_{P}}{\dot{m}_{\text {fuel }} \times L H V_{\text {fuel }}}$

Where,

$\mathrm{H}_{\mathrm{R}}$, enthalpy of the reactants;

$\mathrm{H}_{\mathrm{P}}$, enthalpy of the products;

$\dot{m}_{\text {fuel }}$, fuel mass flow rate $[\mathrm{kg} / \mathrm{h}]$.

$\mathrm{LHV}_{\text {fuel }}$, lower heat value $[\mathrm{MJ} / \mathrm{kg}]$;

The thermal efficiency by its turn is calculated by the ratio of the indicated engine power to the energy released by the fuel combustion, as shown in equation (4).

$\eta_{t}=\frac{P_{\text {ot }} \text { ind }}{H_{R}-H_{P}}$

Where,

Pot $_{\text {ind }}$, indicated power;

$\mathrm{H}_{\mathrm{R}}$, enthalpy of the reactants;

$\mathrm{H}_{\mathrm{P}}$, enthalpy of the products.

By combining equations (3) and (4), it is possible to express the fuel conversion efficiency as function of the thermal and combustion efficiencies.

$\eta_{t} \times \eta_{c o m b}=\eta_{c o n v}$

Figure 11.a shows that the compression ratio has great influence on the thermal efficiency of the thermodynamic cycle. It is possible to understand that the thermal energy efficiency increases with the compression ratio. Figure 11.b shows that a rise of the CR resulted in a decrease of the combustion efficiency with clean combustion chamber (without iEGR).

However, the introduction of iEGR associated to the optimization of the flow structure led to better combustion efficiency. Figure 11.c shows that the $\mathrm{CR}$ variation alone did not result in improvements of the fuel conversion efficiency of the same order of magnitude as for the thermal efficiency. That is explained by the fall of the combustion efficiency resulting from higher compression ratios.

It was possible to improve the engine thermal efficiency by the association of new technologies to high volumetric compression ratios, and to improve the efficiency of combustion by iEGR combined with the optimization of the primary flow structure [12]. 

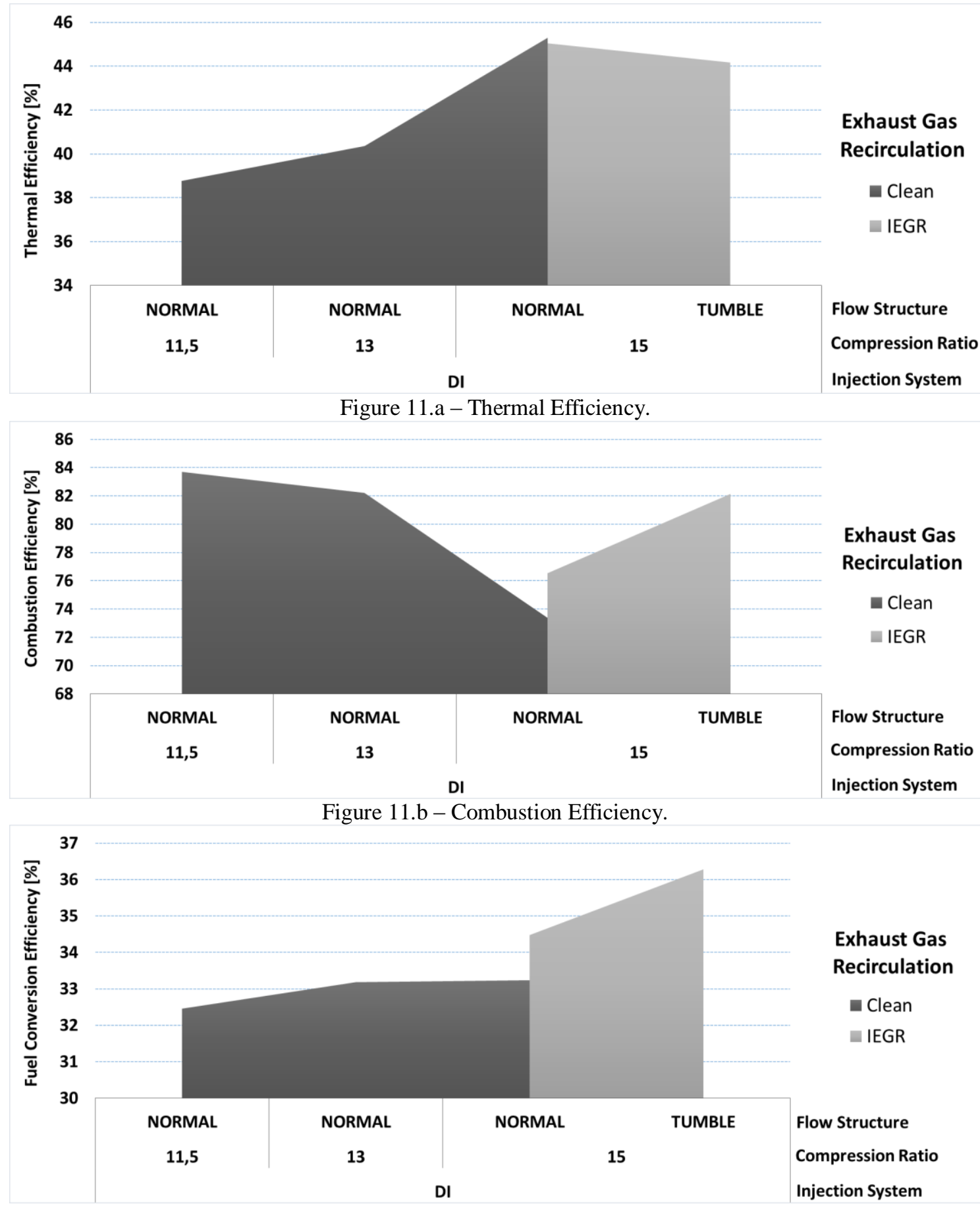

Figure 11.c - Fuel Conversion Efficiency.

Figure 11 - Efficiency analysis for a DI engine using E100 for different CRs. Clean chamber and dirty chamber configurations with tumble generation at 3 bar iMEP and $2500 \mathrm{rpm}$.

The $\mathrm{P} \times \mathrm{V}$ diagrams of figure 12 show different test conditions. For the same operating conditions, the log-log format allows a closer look of the inlet and exhaust regions. It shows the main characteristics related to the operation with different compression ratios, such as higher peak pressures resulting from higher CRs. It is also possible to see the increase of the inlet pressure resulting from the introduction of iEGR. This increase of the inlet pressure and the light decrease of the exhaust pressure in the end of the exhaust stroke led to lower pumping losses with iEGR. The optimization of the flow structure resulted in an 
increase of the peak pressures and of the combustion efficiency, which was translated into higher fuel conversion efficiencies.
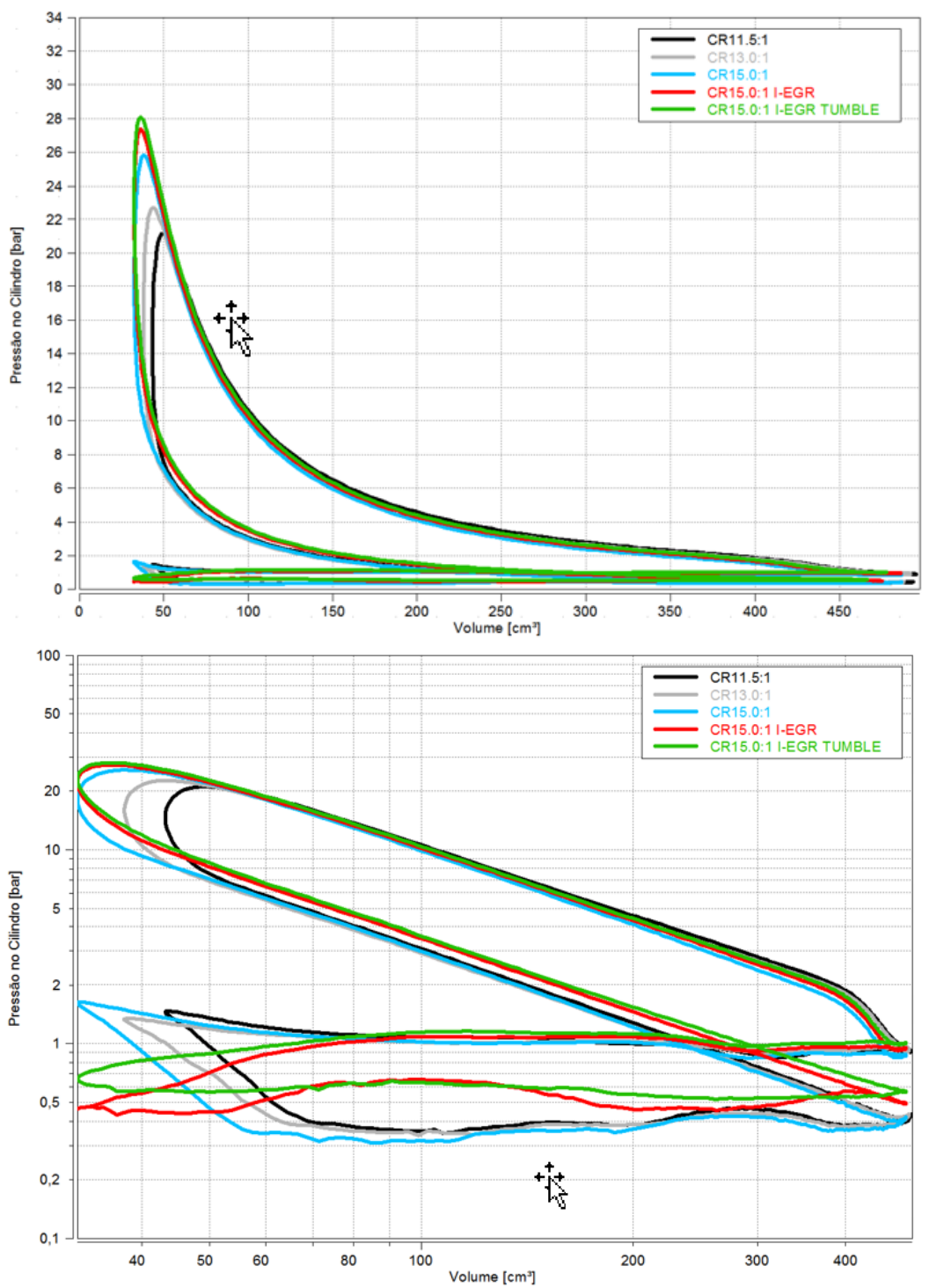

Figure 12 - P x V diagrams showing the influence of the combination of different technologies

\section{CONCLUSIONS}

Tests on a single cylinder research engine allowed a comprehensive study of the influence of different technologies, such as the variation of the compression ratio, PFI and DI injection systems, internal exhaust gas recirculation, and the optimization of the primary flow structure, on the conversion efficiency of ethanol and gasoline.

The tests with a PFI system without iEGR revealed higher efficiency improvements for ethanol than gasoline. The anti-knocking properties of the biofuel explains the differences and justifies why the Flex-Fuel vehicles produced in Brazil are designed with a CR optimized for gasoline, which is a compromise limited by knocking when running the engine with the fossil fuel. The increase of the CR from 11.5 to $15: 1$ with ethanol resulted in average gains of efficiency of 
around $3.4 \%$. This indicates to the possibility of increasing the conversion efficiency of the Flex-Fuel engines by optimizing the compression ratio according to the type of fuel. Numerical simulations with ethanol and a CR of 16:1 resulted in extra gains of efficiency that will be reported in another paper.

The direct injection of fuel in the combustion chamber promoted a cooling effect in the combustion chamber. This explains the better knocking behavior of DI engines as compared to PFI engines. Direct injection allowed additional gains of efficiency even when running with gasoline and high CR at high loads. However, it is important to mention that the use of E22 at high loads and high CR is limited by knocking. It is also worthy to mention that the knocking phenomena were less intensive with DI than with the PFI version of the engine.

The iEGR strategy was tested on the PFI version, through the anticipation of the inlet valve opening. This technology allowed the mitigation of knocking events when high CR and E22 were used. It also brought benefits by reducing the pumping losses and the $\mathrm{NO}_{\mathrm{x}}$ and $\mathrm{CO}$ emission. The fuel consumption reduction resulting from the introduction of iEGR was more expressive at low loads, since in these operating conditions the relative contribution of the pumping power is more relevant. The average flame temperature also decreased and contributed to the mitigation of knocking when the engine used high CR and E22. A reduction of the CO emission relates to better combustion efficiency resultant from the introduction of iEGR.

However, the use of iEGR has side effects that led to the reduction of the speed of combustion, which was indicated by the necessity to advance the ignition timing in order to keep the MBF at $8^{\circ} \mathrm{ATDC}$, and by a longer MBF10-90 when running with dirty combustion chamber.

The association of the optimization of the primary flow structure with iEGR helped to recover the combustion efficiency and to maximize the fuel conversion efficiency. The combination of these technologies on a DI engine led to a reduction of $10 \%$ in the specific fuel consumption for an operating condition of 3 bar IMEP and $2500 \mathrm{rpm}$. It is important to note that this operating point corresponds to a favorable condition for the application of these technologies. However, a more comprehensive study including additional operating conditions will help to understand the full benefits of each of these technologies.

This is only a small segment of all the possibilities to be explored in the search for alternative fuels and technologies to improve the efficiency of Flex-Fuel engines. The possibility to design engines with high volumetric $\mathrm{CR}$ and optimized for ethanol, without compromising the durability and performance when running with gasoline, represents one of the many technological challenges that will bring benefits to society and the environment.

\section{REFERENCES}

[1] Associação Brasileira de Engenharia Automotiva, "Eficiência Energética Sustentável". Available on http://www.mme.gov.br/web/guest/consultaspublicas?p_auth=S9oRfP0R\&p_p_id=consultapublicaexterna_WAR_consultapublicaportlet\& $\mathrm{p} p$ lifecycle $=1 \& p$ p state $=$ normal $\& p$ p mode $=$ view $\& p \quad p$ col $i d=$ column-

$1 \& p \_p \_c o l \_c o u n t=1 \& \_c o n s u l t a p u b l i c a e x t e r n a \_W A R \_c o n s u l t a p u b l i c a p o r t l e t \_o b j I d=277 \& \_c$ onsultapublicaexterna WAR consultapublicaportlet javax.portlet.action=downloadParticipac ao, accessed April 2017. 
[2] Engine Technology International, "Fleet trialling sustainable ethanol fuel". Available on http://www.enginetechnologyinternational.com/exclusive_articles.php?ArticleID=2076, accessed April 2017.

[3] Automotive Business, "Nissan conclui ciclo de teste de carro a célula de combustível com etanol". Available on http://www.automotivebusiness.com.br/noticia/25775/nissan-concluiciclo-de-teste-de-carro-a-celula-de-combustivel-com-etanol, accessed April 2017.

[4] Engine Technology International, "Engines on Test: MG SGE-LFV GDI 1.5 liter". Available

on

http://www.enginetechnologyinternational.com/exclusive_articles.php?ArticleID=2078, accessed April 2017.

[5] RODRIGUEZ, Henrique; Revista Quatro Rodas, "Por que a Volkswagen vai trocar o motor 1.4 TSI pelo 1.5 TSI?”. Available on http://www.quatrorodas.abril.com.br/noticias/por-que-avolkswagen-vai-trocar-o-motor-1-4-tsi-pelo-1-5-tsi/, accessed April 2017.

[6] Revista Carros, "Novo motor 1.5 TSI EVO chega ao Volkswagen Golf". Available on http://revistacarros.sapo.pt/novo-motor-1-5-tsi-evo-chega-ao-volkswagen-golf/, accessed April 2017.

[7] Engine Technology International, "Exclusive Interview: Alain Raposo". Available on http://www.enginetechnologyinternational.com/exclusive_articles.php?ArticleID=1990, accessed April 2017.

[8] Engine Technology International, "Toyota announces all-new 1.5 liter Petrol engine". Available on http://www.enginetechnologyinternational.com/news.php?NewsID=83601, accessed April 2017.

[9] AVL LIST GMBH, "Single Cylinder Research Engine 5405.95 Manual”. Austria, 2014.

[10] Ministério do Desenvolvimento, Indústria e Comércio Exterior; Instituto Nacional de Metrologia, Qualidade e Tecnologia, "Aperfeiçoamento dos Requisitos de Avaliação da Conformidade para Veículos Leves de Passageiros e Comerciais Leves", Portaria n. ${ }^{\circ} 285$, de 19 de junho de 2015. Available on http://www.inmetro.gov.br/legislacao/rtac/pdf/ RTAC002264.pdf, accessed June 2017.

[11] Gomes, P., et al., "Study on Boosted Direct Injection SI Combustion with Ethanol Blends and the Influence on the Ignition System", SAE Technical Paper 2011-36-0196, 2011, doi: 10.4271/2011-36-0196.

[12] Financiadora de Estudos e Projetos, "Relatório de Acompanhamento Técnico de Projetos", Ref. FINEP 0391/14, pag. 4, número de contrato: 03.15.0036.00, December 2016.

\section{ACKNOWLEDGMENTS}

Special thanks to FINEP, CNPq and Robert Bosch GmbH for funding this project.

\section{DEFINITIONS/ABBREVIATIONS}

$\begin{array}{llll}\text { ATDC } & \text { After Top Dead Center } & \text { iFCE } & \begin{array}{l}\text { Indicated Fuel } \\ \text { Conversion } \\ \text { Efficiency }\end{array} \\ \text { Net Indicated Mean } \\ \text { BMEP } & & \begin{array}{l}\text { Effective Pressure } \\ (720 \text { degree crank } \\ \text { angle })\end{array} \\ \text { Praksure Mean Effective } & \text { iMEP } & \begin{array}{l}\text { Lower Heating Value } \\ \text { or Lower Calorific } \\ \text { Value }[\mathrm{MJ} / \mathrm{kg}]\end{array}\end{array}$




\begin{tabular}{|c|c|c|c|}
\hline CNPq & $\begin{array}{l}\text { Conselho Nacional de } \\
\text { Desenvolvimento } \\
\text { Científico e Tecnológico }\end{array}$ & MBF10-90 & $\begin{array}{l}\text { Mass Burn Fraction } \\
\text { from } 10 \% \text { to } 90 \%\end{array}$ \\
\hline COP21 & $\begin{array}{l}\text { UN Conference on } \\
\text { Climate Change held } \\
\text { from 30/11 to } \\
11 / 12 / 2015 \text { in Paris }\end{array}$ & MBF50 & $\begin{array}{l}\text { Mass Burn Fraction } \\
50 \%\end{array}$ \\
\hline CR & $\begin{array}{l}\text { Geometric Compression } \\
\text { Ratio }\end{array}$ & $\dot{\boldsymbol{m}}_{\text {fuel }}$ & $\begin{array}{l}\text { Fuel Mass Flow Rate } \\
{[\mathrm{kg} / \mathrm{h}]}\end{array}$ \\
\hline CTM & $\begin{array}{l}\text { Centro de Tecnologia da } \\
\text { Mobilidade }\end{array}$ & PFI & Port Fuel Injection \\
\hline DI & Direct Fuel Injection & PMEP & $\begin{array}{l}\text { Pumping Mean } \\
\text { Effective Pressure }\end{array}$ \\
\hline E22 & $\begin{array}{l}\text { Gasoline used for } \\
\text { homologation tests }\end{array}$ & Pot $_{\text {ind }}$ & $\begin{array}{l}\text { Indicated Power } \\
{[\mathrm{kW}]}\end{array}$ \\
\hline EVC & Exhaust Valve Close & RenovaBio & $\begin{array}{l}\text { Initiative of the } \\
\text { Ministry of Mines } \\
\text { and Energy that seeks } \\
\text { to promote the use of } \\
\text { biofuels }\end{array}$ \\
\hline FINEP & $\begin{array}{l}\text { Financiadora de Estudos } \\
\text { e Projetos }\end{array}$ & RPM & $\begin{array}{l}\text { Revolutions per } \\
\text { minute }\end{array}$ \\
\hline Flex-Fuel & $\begin{array}{l}\text { Term used to describe } \\
\text { vehicles powered by } \\
\text { gasoline E22, ethanol } \\
\text { E100 or any ratio } \\
\text { between E22 and E100 }\end{array}$ & SCRE & $\begin{array}{l}\text { Single Cylinder } \\
\text { Research Engine }\end{array}$ \\
\hline FTP75 & $\begin{array}{l}\text { American emissions test } \\
\text { procedure (Federal Test } \\
\text { Procedure } 75)\end{array}$ & SI & Spark Ignition \\
\hline GHG & Greenhouse gases & UFMG & $\begin{array}{l}\text { Universidade Federal } \\
\text { de Minas Gerais / } \\
\text { Minas Gerais Federal } \\
\text { University }\end{array}$ \\
\hline iEGR & $\begin{array}{l}\text { Internal Exhaust Gas } \\
\text { Recirculation }\end{array}$ & WOT & Wide Open Throttle \\
\hline
\end{tabular}

